\title{
INTERAKSI MASYARAKAT DENGAN HUTAN DAN LINGKUNGAN SEKITARNYA DI KAWASAN DAN DAERAH PENYANGGA \\ TAMAN NASIONAL KUTAI
}

\section{(Community Interaction with Forest and their Environment in Kutai National Park and its Bufferzone)*)}

\author{
Oleh/By: \\ Reny Sawitri ${ }^{1)}$, Sri Suharti ${ }^{1)}$ dan/and Endang Karlina ${ }^{1)}$ \\ e-mail: suharti23@yahoo.co.id \\ ${ }^{1)}$ Pusat Penelitian dan Pengembangan Konservasi dan Rehabilitasi \\ Jl. Gunung Batu No. 5 PO BOX 165; Telp.0251-8633234, 7520067; Fax 0251-8638111 Bogor
}

*)Diterima : 20 September 2010; Disetujui : 23 Juli 2011

\begin{abstract}
Kutai National Park (Kutai NP) with the total area of 198,629 ha has been encroached by local community from different ethnic groups and utilized for settlement, plantation, area and fish pond. Area that has been occupied is 53,629 ha (27\%), and the rest of it, or around 145,000 ha (73\%) is undisturbed. The objective of the research was to study community interaction both inside Kutai NP and its buffer zone. The research was done by interviewing respondents which were purposively selected. Community interaction was differentiated based on different social economic and cultural background i.e from Dayak Kutai, Java and Bugis ethnics. Community interaction inside Kutai NP had the main objective to expand cultivated land, while for local government it was intended for land expansion to endorse decentralization program Overcoming the problem of land encroachment inside Kutai NP is recommended to be based on conservation efforts to restore Kutai NP. Whereas conservation and development utilization of potential natural resources including local/endemic plant biodiversity such as fruit trees and natural coloring material need to be introduced and cultivated in both local community and new inhabitant community land.
\end{abstract}

Keywords: Ethnic groups, typology, encroachment areas

\begin{abstract}
ABSTRAK
Taman Nasional Kutai (TNK) seluas 198.629 ha, sejak tahun 2000-an mulai dirambah penduduk untuk dimanfaatkan sebagai tempat pemukiman, lahan perkebunan dan tambak seluas 53.629 ha (27\%), sehingga hutan yang tersisa dan masih utuh sekitar 145.000 (73\%). Penelitian ini bertujuan untuk memperoleh informasi tentang kondisi interaksi masyarakat di dalam kawasan maupun daerah penyangga TNK, melalui wawancara dengan responden sebanyak 33 KK (Kepala Keluarga) yang dipilih secara purposive. Keterkaitan masyarakat dengan TNK dibedakan berdasarkan tipologi masyarakat berlatar belakang sosial ekonomi dan budaya berbeda yaitu dari etnis Dayak, Kutai, Jawa dan Bugis. Interaksi masyarakat ke dalam kawasan TNK dilakukan dengan berbagai tujuan antara lain untuk memperluas lahan garapan masyarakat, sedangkan bagi pemerintah daerah dilakukan guna memperluas daerah dalam rangka otonomi daerah. Untuk mengatasi masalah perambahan hutan hendaknya didasarkan pada aspek konservasi untuk mengembalikan fungsi kawasan TNK seperti semula, sedangkan pelestarian dan pengembangan pemanfaatan potensi sumberdaya alam yang termasuk keanekaragaman tumbuhan lokal dan endemik Kalimantan seperti buah-buahan dan bahan pewarna perlu disosialisasikan dan dibudidayakan di kebun rakyat baik untuk masyarakat lokal maupun pendatang.
\end{abstract}

Kata kunci: Kelompok etnik, tipologi dan perambahan hutan

\section{PENDAHULUAN}

Taman Nasional Kutai yang ditetapkan berdasarkan Keputusan Menteri Ke- hutanan No.325/Kpts-II/1995 dengan luas 198.629 ha, memiliki berbagai tipe vegetasi utama yaitu vegetasi hutan pantai, hutan mangrove, hutan rawa air tawar, 
hutan kerangas, hutan genangan dataran rendah, hutan ulin/meranti/kapur dan hutan Dipterocarpaceae campuran (Direktorat Jendral Perlindungan Hutan dan Konservasi Alam, 2003). Disamping itu, dijumpai keanekaragaman satwa mamalia seperti beberapa jenis primata yaitu orang utan (Pongo pygmaeus Mario Linnaeus, 1760), owa kalimantan (Hylobates muelleri Kloss, 1929), bekantan (Nasalis larvatus Wurmb, 1787), kera ekor panjang (Macaca fascicularis Raffles,1823), beruk (Macaca nemestrina Linnaeus,1766) dan kukang (Nycticebus coucang borneanus Boddaert,1787); jenis ungulata diantaranya adalah banteng (Bos javanicus lowi Lydekker,1912), rusa sambar (Cervus unicolor brookii Kerr.,1792), kijang (Muntiacus muntjak pleiharicus Zumernam, 1780) dan kancil (Tragulus javanicus klossi Osbech, 1765); jenis karnivora seperti beruang madu (Helarctos Malayanus euryspilus Raffles, 1821 ) dan kucing kepala datar (Priohailurus planiceps Vigors dan Horsfield,1827) (BAPPENAS, 2003).

Namun, sejak tahun 2000-an, taman nasional ini menghadapi permasalahan seperti kebakaran hutan, pembalakan illegal dan perambahan oleh masyarakat yang membuka lahan untuk pemukiman, perladangan serta prasarana umum (Taman Nasional Kutai, 2010). Kerusakan habitat ini mengakibatkan satwa liar seperti orangutan yang populasinya hanya tinggal sekitar 2.000 individu, mencari makan ke luar kawasan taman nasional yaitu ke daerah penyangga seperti kebun rakyat dan hutan tanaman industri (HTI) PT. Surya Hutani Jaya. Di daerah ini orangutan mencari pakan berupa palawija serta kulit dan daun muda akasia (Acacia auriculiformis) (Ambrosium, 2010)

Dampak perambahan hutan menyebabkan berkurangnya luas kawasan hutan, saat ini luas kawasan hutan yang masih tersisa sekitar 145.000 ha atau $73 \%$, berupa hutan primer, sekunder, rawa, belukar rawa, mangrove, sedangkan sisanya 53.629 ha atau $27 \%$, berupa belukar, semak, alang-alang, tanah terbuka, tambak, pertanian campuran, pemukiman masyarakat serta sarana dan prasarana (Taman Nasional Kutai, 2010).

Pembangunan industri di bidang pertambangan batubara, pembuatan pupuk dan pengolahan kayu memacu kedatangan masyarakat pendatang ke Kalimantan Timur. Perusahaan-perusahaan tersebut diantaranya adalah PT. Kaltim Prima Coal, PT. Pupuk Bontang, PT. Pupuk Kaltim, HTI PT. Surya Hutani Jaya dan HTI PT. Kiani Lestari. Lokasi perusahaan terletak di perbatasan TNK atau di daerah penyangganya. Dengan berjalannya waktu, banyak pekerja perusahaan yang pada akhirnya mengalami pemutusan hubungan kerja (PHK) seperti yang terjadi pada ex HTI PT. Kiani Lestari. Sebagai akibatnya, karena keterbatasan pengetahuan dan keterampilan yang dimiliki, mereka melakukan pembukaan hutan dan memanfaatkan sumberdaya alam di TNK untuk membangun rumah dan berladang. Selanjutnya, masyarakat transmigran atau pendatang dan masyarakat lokal yang mengetahui hal ini kemudian beranggapan bahwa perambahan hutan merupakan suatu peluang untuk memperluas lahan garapan dan meningkatkan pendapatan. Penelitian ini bertujuan untuk memperoleh informasi tentang kondisi interaksi masyarakat di dalam kawasan maupun daerah penyangga TNK, melalui wawancara dengan responden sebanyak $33 \mathrm{KK}$ (Kepala Keluarga) yang dipilih secara purposive. Selanjutnya penelitian ini juga mencoba, memberikan beberapa alternatif solusi dari permasalahan perambahan hutan yang terjadi dalam bentuk interaksi masyarakat dengan kawasan untuk mendukung pengelolaan kawasan yang lestari. Diharapkan hasil penelitian ini bermanfaat bagi beberapa pihak yang terkait dan turut menangani permasalahan ekologi dan sosial ekonomi di daerah penyangga Taman Nasional Kutai, sehingga kelestarian taman nasional ini dapat dipertahankan. 


\section{BAHAN DAN METODE}

\section{A. Waktu dan Lokasi Penelitian}

Pengamatan lapangan dilakukan pada bulan Maret tahun 2009, bertempat di daerah penyangga dan di dalam kawasan TNK dimana masyarakatnya merupakan masyarakat campuran, yaitu lokal dan pendatang dari berbagai etnis seperti Kutai, Dayak, Banjar, Bugis, Tator dan Jawa. Masyarakat yang tinggal di daerah penyangga adalah penduduk Desa Singa Geweh. Sedangkan, masyarakat yang langsung berkaitan dengan TNK dengan melakukan perambahan hutan dan pemanfaatan sumberdaya alam berupa potensi biologi dan ekologi adalah etnis Kutai, Dayak, Jawa dan Bugis.

\section{B. Bahan dan Alat Penelitian}

Bahan yang digunakan dalam penelitian ini adalah peta kerja kawasan TNK (1:250.000) untuk mengetahui kawasan yang dirambah, buku identifikasi burung dan ikan, serta kuesioner, sedangkan peralatannya adalah kamera, binokuler, alat ukur tinggi pohon dan pita diameter.

\section{Metode Penelitian}

\section{Prosedur Kerja}

Data yang dikumpulkan meliputi tipologi masyarakat, sosial ekonomi, teknis pengelolaan lahan dan pemanfaatan sumberdaya alam oleh masyarakat. Hal ini dilakukan melalui wawancara dengan responden yang dipilih dan dianggap dapat mewakili, serta menggunakan kuesioner yang telah disiapkan sebelumnya. Data sekunder berasal dari monografi desa dan studi pustaka. Jumlah responden untuk tiap etnis tergantung pada jumlah KK yang ada serta tingkat keterkaitannya dengan pemanfaatan sumberdaya alam. Responden di masing-masing etnis ratarata $25-30 \%$ adalah sebagai berikut: etnis Kutai (10 KK dari $30 \mathrm{KK})$, etnis Dayak (5 KK dari $20 \mathrm{KK}$ ), etnis Jawa ( $8 \mathrm{KK}$ dari $22 \mathrm{KK}$ ) dan etnis Bugis (10 KK dari $35 \mathrm{KK})$.

\section{Analisis Data}

Data dan informasi dikompilasi dalam bentuk tabel yang dianalisis secara deskriptif dan evaluatif yang meliputi tipologi masyarakat di daerah penyangga dan di dalam kawasan TNK, potensi dan pemanfaatan sumberdaya alam oleh masyarakat lokal dan pendatang serta pola usahatani kebun rakyat pada berbagai etnis di daerah penyangga TNK. Disamping itu dicoba dirumuskan beberapa alternatif solusi dari permasalahan perambahan hutan untuk mendukung pengelolaan kawasan yang lestari. Identifikasi jenis tumbuhan dilakukan di laboratorium herbarium Pusat Litbang Konservasi dan Rehabilitasi.

\section{HASIL DAN PEMBAHASAN}

\section{A. Tipologi Masyarakat di Kawasan dan Daerah Penyangga TN Kutai}

Masyarakat yang ada di daerah penyangga dan di dalam kawasan TNK berasal dari berbagai etnis seperti Kutai, Dayak, Banjar, Bugis, Tator dan Jawa.Kampung Jawa merupakan wilayah dimana masyarakat yang berasal dari etnis Jawa bertempat tinggal dengan jumlah penduduk sebanyak 22 KK. Mayoritas penduduk kampung Jawa adalah peserta transmigran yang datang ke Provinsi Kalimantan Timur pada tahun 1992. Sementara itu, penduduk Desa Singa Geweh berasal dari beberapa etnis yang berbeda yaitu Kutai, Dayak dan Banjar. Pola interaksi dengan lingkungan setempat serta pola usahatani yang dikembangkan oleh ketiga etnis tersebut cukup beragam. Selain memiliki lahan garapan sendiri, warga masyarakat juga melakukan pembukaan lahan di dalam kawasan TNK. Populasi warga di Singa Geweh yang memasuki wilayah TNK untuk membuka lahan dan berusahatani sekitar $50 \mathrm{KK}$ yang berasal dari ketiga etnis tersebut di atas.

Kelompok besar tersebut terbagi lagi ke dalam sub-sub kelompok yang beranggotakan rata-rata 10 jiwa. Luas lahan ga- 
rapan rata-rata di dalam TNK sekitar 2 ha. Tujuan pembukaan lahan selain untuk budidaya tanaman pangan semusim juga untuk budidaya tanaman tahunan seperti karet. Perambahan lahan di dalam kawasan hutan TNK terjadi sangat ekstensif, bahkan pengalihan lahan garapan sudah banyak terjadi dengan cara diperjualbelikan. Tujuan perambahan lahan di dalam kawasan hutan TNK selain untuk mendapatkan lahan garapan, juga untuk mendapatkan kayu ulin (terutama suku Dayak yang mengambil ulin baik untuk bahan bangunan ataupun diperjualbelikan).

Deskripsi umum masyarakat di kawasan dan daerah penyangga TNK digambarkan oleh identitas responden, seperti disajikan pada Tabel 1.

Masyarakat etnis Jawa yang merupakan pendatang ke daerah Sangata sebagian besar adalah transmigran atau pekerja di industri perkayuan seperti HPH atau HTI. Sebagai transmigran, masyarakat etnis Jawa yang mereka berusaha di bidang pertanian dan memiliki lahan garapan yang cukup luas sekitar lima ha yang dikelola secara intensif dengan tanaman buah-buahan, perkayuan, sayursayuran dan tanaman obat-obatan. Jenis tanaman yang dibudidayakan dengan sistem agroforestri tersebut merupakan jenis tanaman yang bernilai ekonomis untuk memenuhi pendapatan rumah tangga sehari-hari.

Masyarakat etnis Bugis sebagian merupakan pendatang, mempunyai mata pencaharian sebagai pemasok bahan bangunan berupa pasir dan semen dari Sulawesi dengan menggunakan angkutan kapal laut. Disamping itu ada juga yang mempunyai mata pencaharian sebagai nelayan yang bertempat tinggal di daerah pantai dengan jumlah anggota keluarga relatif sedikit (rata-rata tiga jiwa).

Sedangkan masyarakat lokal seperti etnis Dayak dan Kutai, rata-rata mereka memiliki kebun seluas 4-5 ha, namun tidak diusahakan secara intensif. Hal ini terlihat dari jenis tanaman yang dibudida- yakan, yaitu tanaman kayu-kayuan dan buah-buahan seperti durian (Durio zibethinus Lamk), rambutan (Nephelium lappaceum L.), jeruk (Citrus sp.), duku (Lansium domesticum Corr.), pisang (Musa sp.), kwanyi (Mangifera spp.), manggis hutan (Garcinia celebica Linn.) serta tanaman industri karet (Hevea brasiliensis Muell.Arg.).

Secara umum, interaksi antara masyarakat dengan hutan dan sekitarnya di kawasan dan daerah penyanggga TN Kutai serta pola usahataninya tercantum pada Lampiran 1.

Interaksi masyarakat etnis Jawa dengan lingkungan biofisik yang ada di sekitarnya cukup erat, hal ini terlihat dari pembukaan lahan garapan, intensitas sistem budidaya tanaman, jenis tanaman, dan pola tanam yang diterapkan di kawasan dan daerah penyangga TNK. Disamping untuk mendapatkan lahan garapan, masyarakat juga memanfaatkan jenis pohon yang ditemukan di kawasan untuk bahan bangunan, kapal dan kayu bakar. Jenis jamur dan beberapa jenis satwaliar seperi babi hutan dimanfaatkan untuk dikonsumsi. Babi butan selain dikonsumsi juga digunakan untuk sesajen.

Etnis Kutai dan Bugis memiliki beberapa persamaan dalam melaksanakan kegiatan usahataninya, namun dalam pemeliharaan tanaman etnis Bugis lebih intensif.

\section{B. Potensi Pemanfaatan Sumberdaya Alam}

Potensi sumberdaya alam yang ada di kawasan dan daerah penyangga TNK cukup besar. Masyarakat umumnya sudah memanfaatkan berbagai jenis tanaman lokal yang terdapat di sekitar tempat tinggal baik untuk pemenuhan kebutuhan sendiri (subsisten) maupun untuk diperjualbelikan (Tabel 2). Jenis tanaman lokal tersebut umumnya sebagai penghasil buah dan kayu untuk bahan bangunan. Disamping itu, masyarakat juga memanfaatkan keanekaragaman hayati satwaliar 
yang termasuk jenis ikan, burung dan mamalia (Lampiran 1 dan Lampiran 2). Pohon buah-buahan lokal tersebut dipanen dari hutan, dikelola dalam hutan atau setengah dibudidayakan di pekarangan atau di kebun rakyat. Keanekaragaman jenis

Tabel (Table) 1. Identitas responden berbagai etnis di daerah penyangga TNK (Respondent identity of different ethnic groups in TN Kutai buffer zone)

\begin{tabular}{|c|c|c|}
\hline Kriteria (Criteria) & Pendatang (New inhabitant) & $\begin{array}{l}\text { Penduduk Lokal (Local } \\
\text { community) }\end{array}$ \\
\hline $\begin{array}{l}\text { Asal etnis (Etnic) } \\
\text { Umur rata-rata (Average age) } \\
\text { Eanggota keluarga (Number of family } \\
\text { member) }\end{array}$ & $\begin{array}{l}\text { Jawa, Bugis } \\
35-40 \text { tahun } \\
4-5 \text { orang }\end{array}$ & $\begin{array}{l}\text { Dayak, Kutai } \\
40-50 \text { tahun } \\
4-8 \text { orang }\end{array}$ \\
\hline $\begin{array}{l}\text { Mata pencaharian (Livelihood) } \\
\text { 1) Utama (Main) }\end{array}$ & Petani (farmer) & $\begin{array}{l}\text { - Buruh/labour KPC, } \\
\text { - PNS/goverment official, } \\
\text { - usaha kapal ponton/ } \\
\text { shipman. }\end{array}$ \\
\hline 2) Sampingan (Secondary) & $\begin{array}{l}\text { Berdagang sayur }{ }^{2} \text { an (sale } \\
\text { vegetables) }\end{array}$ & Petani/farmer \\
\hline $\begin{array}{l}\text { Pemilikan lahan (Land holding) } \\
\text { 1) Lahan garapan di areal trans } \\
\text { (Cultivated land on transmigration } \\
\text { land) }\end{array}$ & $\begin{array}{l}\text { - Pekarangan (homeyard): } \\
0,25 \text { ha } \\
\text { - Kebun I : } 0,75 \text { ha } \\
\text { - Kebun II : } 1 \text { ha }\end{array}$ & $420 \mathrm{~m} 2$ \\
\hline $\begin{array}{l}\text { 2) Lahan garapan (milik sendiri)(Private } \\
\text { owned cultivated land) }\end{array}$ & $0,90-1$ ha & 3 ha \\
\hline $\begin{array}{l}\text { 3) Lahan garapan (pinjam) (Cultivated } \\
\text { rent land) }\end{array}$ & 1 ha & \\
\hline $\begin{array}{l}\text { 4) Lahan garapan (dalam TNK) } \\
\text { (Cultivated land inside National Park } \\
\text { Kutai) }\end{array}$ & 1 ha & $2-5$ ha \\
\hline $\begin{array}{l}\text { Jenis tanaman yang dibudidayakan } \\
\text { (Cultivated crop species): }\end{array}$ & & \\
\hline 1) Lahan Trans (Transmigration area) & $\begin{array}{l}\text { - Kebun buah-buahan dan } \\
\text { perkayuan (woody and fruit } \\
\text { crop plantation) } \\
\text { - Budidaya sayur-sayuran } \\
\text { (vegetable crop cultivation) }\end{array}$ & $\begin{array}{l}\text { - Kebun buah-buahan dan } \\
\text { perkayuan (woody and } \\
\text { fruit crop plantation) } \\
\text { - Tanaman pangan semusim, } \\
\text { kebun buah-buahan dan } \\
\text { karet (seasonal food crop, } \\
\text { fruit and rubber } \\
\text { plantation) }\end{array}$ \\
\hline 2) Lahan milik (Private owned land) & $\begin{array}{l}\text { - Budidaya tanaman buah- } \\
\text { buahan (fruit crop } \\
\text { cultivation) } \\
\text { - Budidaya tanaman obat } \\
\text { (medicinal plant } \\
\text { cultivation) }\end{array}$ & \\
\hline $\begin{array}{l}\text { Penggunaan saprotan (use of } \\
\text { production input) }\end{array}$ & $\begin{array}{l}\text { Urea, TSP, } \mathrm{KCl} \text { dan pupuk } \\
\text { organik/kompos (Urea, TSP, } \\
\text { KCL and organic fertilizer/ } \\
\text { green manure) }\end{array}$ & $\begin{array}{l}\text { Urea dan pupuk kandang } \\
\text { (urea and dung) }\end{array}$ \\
\hline $\begin{array}{l}\text { Rata-rata pengeluaran (average } \\
\text { expenditure): }\end{array}$ & $\begin{array}{l}\mathrm{Rp} 50.000 \text { - } 60.000 / \text { hari } \\
\text { (kebutuhan beras rata }{ }^{2} 0,25 \\
\mathrm{~kg} / \mathrm{kapita} / \mathrm{hari} \text { ) (daily rice } \\
\text { necessity } 0.25 \mathrm{~kg} / \text { capita) }\end{array}$ & Rp. $75.000-100.000$ \\
\hline
\end{tabular}

Sumber: Analisis data primer 
Tabel (Table) 2. Jenis tanaman yang berpotensi untuk dikembangkan (Potencial plant species for development)

\begin{tabular}{l|l|l}
\hline Nama Lokal (Local Name) & Nama Latin (Scientific Name) & Keterangan (Remarks) \\
\hline Krantungan & Durio oxleyanus Griff. & Buah (durian) \\
Kasturi & Mangifera casturi Griff. & Buah (mangga) \\
Tarum & Crotalaria sp. & Buah - untuk pewarna \\
Keledang & Artocarpus lanceifolius Roxb. & Buah \\
Ciu/mundar (manggis hutan) & Garcinia celebica Linn. & Buah \\
Maritam & Nephelium juglandifolium Linn. & Buah \\
Durian Lai & Durio spp. & Buah \\
Ramania & Nephelium spp. & Buah \\
\hline
\end{tabular}

Tabel (Table) 3. Jenis burung yang dikonsumsi dan diperjualbelikan (Bird species for consumption and sale)

\begin{tabular}{llc}
\hline Nama lokal (Local name) & Nama Latin (Scientific name) & Harga/ind. (Price/ ind.) (Rp) \\
\hline Rangkong & Rhinoplas vigil Forster & - \\
Punai/Delimukn & Chalcophaps indica L. & $5.000,-$ \\
Kacer & Hemipus hirundinaceus Temminck & $400.000,-$ \\
Beo & Gracula religiosa L. & $100.000,-$ \\
Betet & Loriculus galgulus L. & $15.000,-$ \\
\hline
\end{tabular}
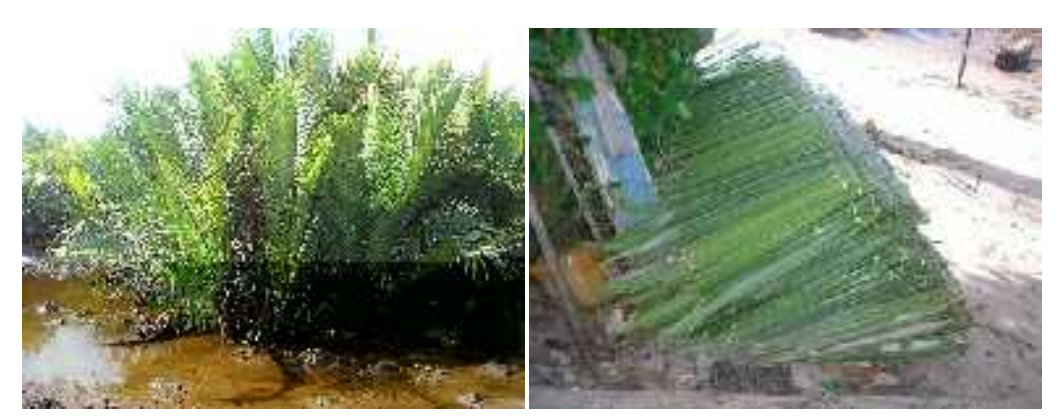

Gambar (Figure) 1. Nipah

(Nypa fruticans), sumber pendapatan tambahan masyarakat etnis Bugis (Nipah as secondary source of income for Bugis etnic) tanaman buah-buahan di Kalimantan cukup tinggi dan beberapa diantaranya termasuk endemik yaitu 24 jenis mangga liar seperti kasturi (Mangifera casturi Griff.) dan 16 jenis rambutan (Nephelium sp.) dan durian (Durio sp.) (Michon, 2005).

Penangkapan ikan dilakukan dengan cara memancing, menjaring, meracun maupun menyetrum. Cara memancing secara tradisional, untuk ikan-ikan kecil seperti ikan seluang (Rasbora spp.) menggunakan umpan kail dari daging buah kelapa, sedangkan untuk jenis ikan lainnya digunakan umpan seperti ulat bambu, usus ayam dan ikan-ikan kecil. Jumlah orang yang memancing di Sungai Sangata adalah sebanyak 10 orang/hari/ dusun dengan hasil rata-rata 3-5 kg/orang. Hasil tangkapan ikan tersebut umumnya dijual atau dikonsumsi sendiri.

Selain memanfaatkan berbagai jenis tanaman yang ada di sekitarnya dan ikan yang ada di sungai tersebut, masyarakat juga memanfaatkan berbagai jenis burung baik untuk keperluan upacara adat, dikonsumsi sendiri maupun diperjualbelikan (Tabel 3).

Kegiatan pengambilan satwa liar dilakukan dalam rangka memenuhi kebutuhan protein, perdagangan, pemeliharaan dan adat istiadat seperti burung rangkong. Satwa diperoleh dengan cara menjerat, menjaring, berburu/menangkap dan membeli.

Selain yang telah diuraikan di atas, ada satu tanaman yang juga banyak dimanfaatkan oleh masyarakat di daerah ini yaitu nipah (Nypa fruticans Wurmb.). Potensi tumbuhan nipah yang terdapat di daerah pesisir Sungai Sangata digunakan untuk membuat atap maupun tikar, sebagai usaha sampingan untuk menambah pendapatan masyarakat (Gambar 1). 


\section{Pola Usahatani Kebun Rakyat Me- nurut Etnis di Daerah Penyangga TN Kutai}

Pola usahatani di kebun yang dibebani hak milik dan dikembangkan oleh masyarakat sangat beragam sesuai dengan tipologi masyarakat pelakunya. Etnis Jawa umumnya lebih menitikberatkan pada sistem usahatani secara intensif dengan budidaya berbagai jenis tanaman pangan semusim dan sayur-sayuran. Sementara pada etnis pendatang, selain menitikberatkan pada budidaya tanaman semusim, lebih menitikberatkan pada pengembangan tanaman serbaguna dan tanaman tahunan lainnya. Pola usahatani di kebun milik pada beberapa kelompok etnis di daerah penyangga TNK adalah sebagai berikut:

\section{Pola Kebun Rakyat Etnis Jawa}

Pola usaha tani di kebun milik masyarakat pendatang yang berasal dari Jawa umumnya didominasi oleh berbagai jenis tanaman pangan semusim seperti jagung (Zea mays Linn.), singkong (Manihot utilissima Pohl.), sayur-sayuran serta berbagai jenis tanaman serbaguna dan tanaman buah-buahan juga tanaman penghasil minyak atsiri seperti nilam (Pogostemon cablin). Deskripsi pola usaha tani pada masyarakat Jawa dapat dilihat pada Gambar 2 .

\section{Pola Kebun Rakyat Etnis Kutai}

Pola usahatani kebun rakyat yang umumnya dikembangkan di kebun rakyat oleh etnis Kutai adalah kombinasi antara berbagai tanaman pangan semusim seperti singkong, sayur-sayuran, tanaman serbaguna serta buah-buahan. Gambaran pola usahatani di kebun milik pada etnis Kutai dapat dilihat pada Gambar 3.

Interaksi masyarakat Kutai dengan lingkungan biofisik yang ada di sekitarnya sangat erat. Berbagai jenis tanaman dimanfaatkan baik sebagai tanaman obat, pewarna alami maupun yang dikonsumsi langsung (buah-buahan).
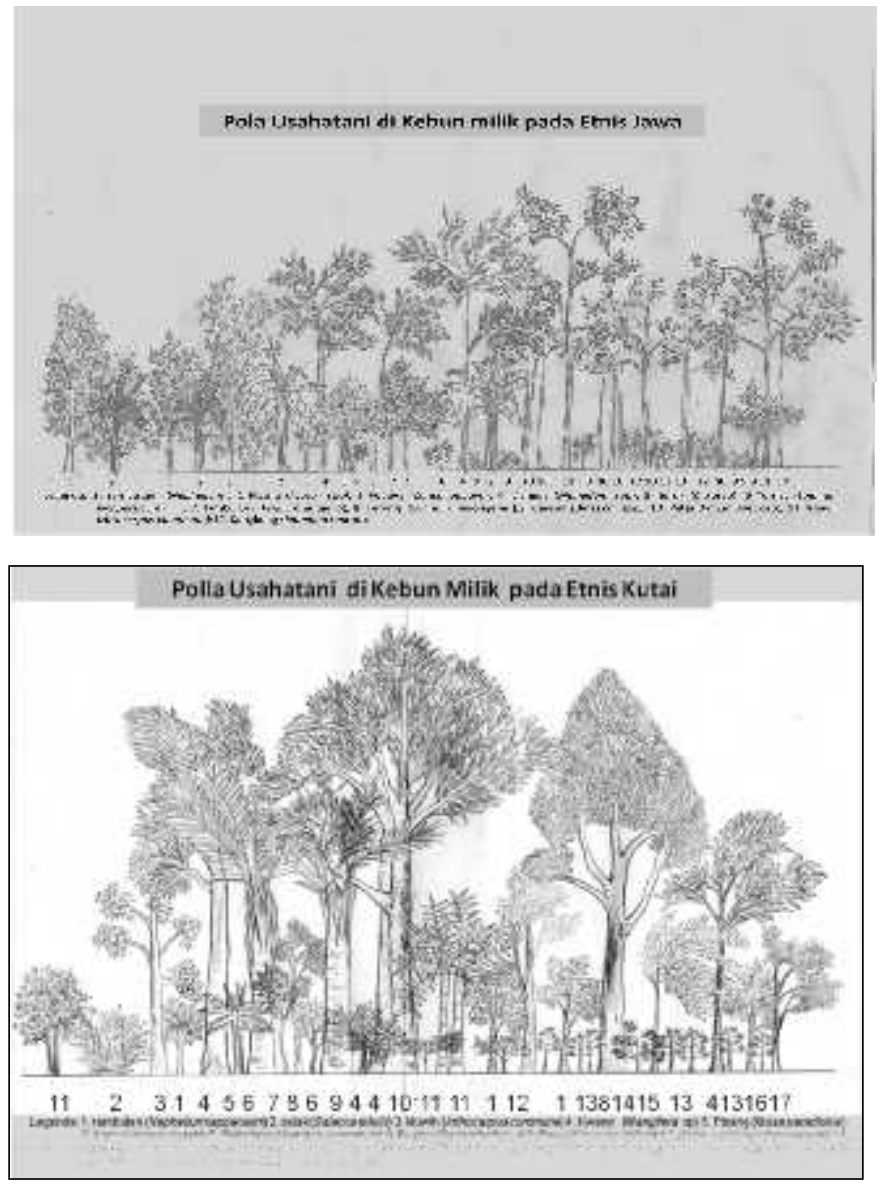

Gambar (Figure) 2. Pola usahatani di kebun milik pada etnis Jawa (Farming pattern of private land of Java ethnic community)

Gambar (Figure) 3. Pola usahatani di kebun milik pada etnis Kutai (Farming pattern of private land of Kutai ethnic community) 


\section{Pola Kebun Rakyat Etnis Bugis}

Jika dibandingkan dengan etnis Kutai dan etnis Jawa, pola usahatani kebun rakyat pada etnis Bugis kurang begitu beragam. Jenis tanaman yang ditemukan didominasi oleh tanaman pangan semusim seperti jagung dan beberapa jenis tanaman buah-buahan seperti nangka (Artocarpus integra Merr.), rambutan (Nephelium lappaceum Linn.) dan kelapa (Cocos nucifera Linn.). Deskripsi pola usahatani di kebun milik pada etnis Bugis dapat dilihat pada Gambar 4.

\section{Interaksi Masyarakat dengan TN Kutai}

Lokasi TNK yang berbatasan langsung dengan tempat pemukiman masyarakat, aksesibilitas cukup tinggi. Di lain pihak, kebutuhan akan lahan garapan sangat tinggi terutama bagi pendatang telah menyebabkan interaksi masyarakat dengan hutan menjadi sangat intensif. Tingginya interaksi ini telah mendorong terjadinya perambahan hutan secara ekstensif di dalam TNK. Luas perambahan saat ini adalah 52.549 ha (TN Kutai, 2008). Kegiatan perambahan di dalam kawasan TNK adalah bercocok tanam tanaman pangan semusim serta berbagai jenis tanaman keras seperti karet, coklat, kopi dan kelapa.

Di dalam kawasan TNK sudah banyak terjadi perambahan hutan yang dilakukan oleh masyarakat sekitar TNK dari berbagai etnis baik pendatang dari luar (Bugis, Jawa) maupun penduduk lokal dari etnis Dayak dan Kutai (Gambar 5).

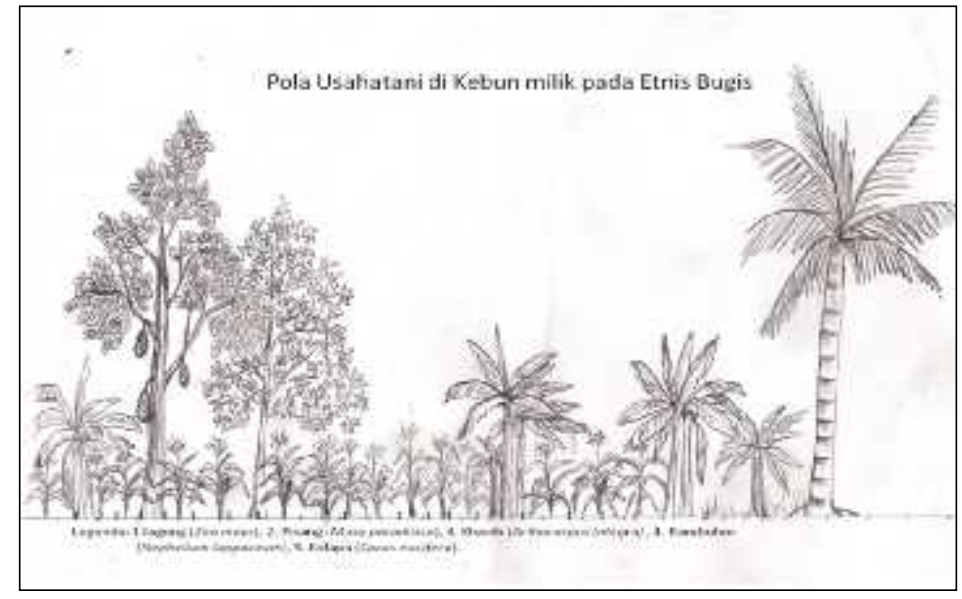

Gambar (Figure) 4. Pola Usahatani di Kebun Milik pada Etnis Bugis (Farming pattern of private land of Bugis ethnic community)

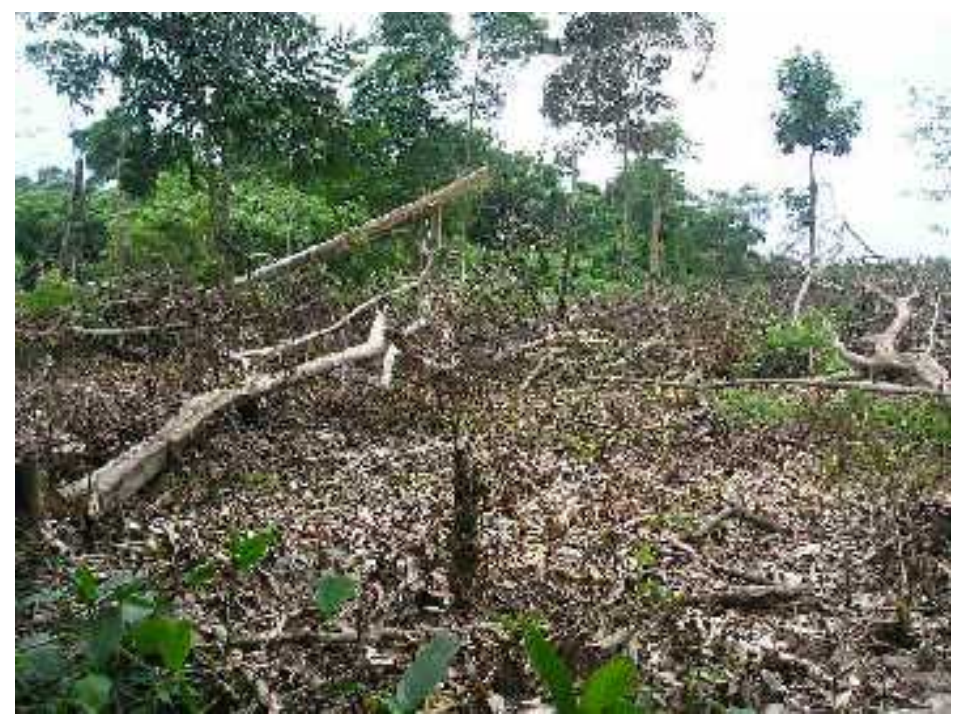

Gambar (Figure) 5. Areal perambahan dalam kawasan TNK (Encroachment areas in Kutai National Park) 
Sejak tahun 2000-an, perambahan yang dilakukan oleh keempat etnis tersebut semakin marak. Walaupun sebetulnya, pola usahatani masyarakat lokal ini berbeda dengan pendatang yang berusahatani secara intensif. Masyarakat Kutai sebagai contohnya, budaya usahatani mereka adalah berladang di kanan kiri sungai, selebar $200 \mathrm{~m}$. Begitu pula motivasi perambahan kawasan TNK sangat bervariasi. Ada yang semata-mata untuk mendapatkan tambahan lahan garapan untuk budidaya tanaman pangan semusim dan tanaman tahunan jangka panjang seperti karet dan kelapa sawit, namun ada juga yang mempunyai tujuan lain seperti penguasaan dan jual beli lahan. Hasil penelitian tentang pola perambahan dan perladangan yang terjadi di kawasan TNK yang dilakukan Subandi (1998) menyebutkan bahwa ditemukan tiga pola perladangan yaitu pola asli, pola adaptasi dan pola komplikasi.

Untuk mengatasi masalah perambahan ini, pihak pengelola TNK sebetulnya sudah mengusulkan untuk menetapkan daerah enclave seluas \pm 24.000 ha. Namun sampai saat ini, areal yang di enclave ini baru sampai pada tahap penunjukan. Di sisi lain, nampaknya pihak Pemerintah Daerah (Pemda) juga kurang memperhatikan masalah perambahan dalam kawasan TNK. Hal ini terlihat dengan ditetapkannya dua kecamatan yaitu Kecamatan Teluk Pandan dan Kecamatan Sangata Selatan serta empat desa definitif, antara lain Sangata Selatan, Singadewe, Sangkima, dan Teluk Pandan oleh Pemda Kutai secara legal formal dalam rangka otonomi daerah. Saat ini Pemda Kutai berencana akan membangun terminal bis di dalam kawasan TNK. Hal ini menunjukkan bahwa ancaman terhadap kelestarian kawasan TNK belum sepenuhnya dirasakan oleh Pemda setempat (Sinar Harapan, 2003).

Jika dilihat dari aspek konservasi, penunjukkan kawasan yang dirambah sebagai daerah enclave sebetulnya akan mem- berikan dampak negatif, karena kawasan yang lainnya akan mencontoh pola perambahan yang demikian, disamping juga perubahan fungsi kawasan menjadi enclave akan mengurangi luas kawasan TNK. Usulan lainnya bagi kawasan yang dirambah adalah pengelolaan zona khusus berdasarkan hasil rapat Kemitraan TNK yang mengarah pada pemanfaatan tradisional. Dengan demikian memungkinkan pengelolaannya di bawah pengawasan pengelola TNK, sehingga diharapkan fungsi kawasan ini dapat kembali seperti semula melalui kegiatan restorasi dan pengelolaan zonasi secara bertahap dari zona pemanfaatan tradisional ke zona restorasi.

\section{KESIMPULAN DAN SARAN}

\section{A. Kesimpulan}

Berdasarkan hasil penelitian ini, tipologi masyarakat berpengaruh terhadap keterkaitannnya di kawasan dan daerah penyangga TNK baik dari segi pengelolaan lahan, pemanfaatan potensi sumberdaya alam, pola usaha tani di lahan garapan dan interaksi dengan hutan, hal ini dapat dilihat bahwa:

1. Pendapatan masyarakat pendatang, etnis Jawa dan Bugis (Rp. 50.000 60.000) lebih kecil dibandingkan masyarakat lokal, etnis Dayak dan Kutai (Rp. 75.000 - 100.000) karena perbedaan luas lahan garapan dan jenis tanaman.

2. Sumberdaya alam yang meliputi jenis tumbuhan buah-buahan lokal/endemik, ikan, burung dan mamalia dari kawasan dan budidaya di daerah penyangga TNK bernilai ekonomi dan dimanfaatkan oleh masyarakat dilakukan untuk memenuhi kebutuhan sendiri (subsisten) maupun diperjual belikan .

3. Pola usaha tani untuk masing-masing etnis memiliki keragaman jenis tanaman yang berbeda, sesuai dengan kebu- 
tuhan sosial ekonomi dan budaya masyarakat Jawa, Kutai dan Bugis.

4. Interaksi masyarakat ke dalam kawasan TNK dilakukan dengan berbagai alasan terutama untuk memperluas lahan garapan. Masyarakat etnis Jawa dan Bugis (1-2 ha), sedangkan masyarakat etnis Dayak dan Kutai (2-5 ha) yang ditanami dengan tanaman pangan semusim, tanaman industri dan tanaman pemukiman. Sedangkan bagi pemerintah daerah, untuk memperluas daerah dalam rangka otonomi daerah.

\section{B. Saran}

1. Permasalahan perambahan hutan di TNK diatasi berdasarkan pada aspek konservasi untuk mengembalikan fungsi kawasan semula dengan pengelolaan kriteria dan indikator yang disepakati antara masyarakat, pengelola, dan mitra TNK. Sebagai contoh adalah tidak memberikan dana/subsidi kepada perambah hutan untuk mengelola tanahnya.

2. Pelestarian dan pengembangan pemanfaatan potensi sumberdaya alam yang termasuk keanekaragaman tumbuhan lokal dan endemik Kalimantan, seperti buah-buahan rambutan, durian, mangga dan nangka serta bahan pewarna yang digunakan etnis Dayak, perlu disosialisasikan dan dibudidayakan di kebun rakyat baik masyarakat lokal maupun pendatang.

\section{DAFTAR PUSTAKA}

Ambrosium H. 2010. Di TN Kutai diduga ada 2000 orangutan. http://regional. kompas.com/read/2010/ob/08/1654

0584. Diakses 1 September 2010.

BAPPENAS. 2003. Dokumen regional, Indonesian biodiversity strategy and action plan. CIFOR. Bogor. Hal. 83-100.

Direktorat Jendral Perlindungan Hutan dan Konservasi Alam. 2003. 41 Taman nasional di Indonesia. Departemen Kehutanan, CIFOR dan UNESCO. Jakarta. Hal 105-106.

Michon, G. 2005. Domesticating forest, how farmers manage forest resources. Center for International Forestry Research The World Agroforestry Centre. Subur Printing, Indonesia. Hal. 101-102.

Sinar Harapan. 2003. Nasib taman nasional Kutai masih menggantung. http://www.tnkutai.com/ index.php/en/news/81-nasib-tamannasional-kutai. Diakses tanggal 1 April 2010. Hal 1-3.

Subandi, 1998. Pola perambahan dan perladangan oleh masyarakat pemukim serta kondisi tegakan pasca perambahan dan perladangan tahun 1986 di kawasan TN Kutai. Fakultas Kehutanan Universitas Mulawarman.

TN Kutai. 2008. TN Kutai terus dirambah. http://www.tnkutai.com/ index.php/innews/85-taman nasional kutai terus dirambah. Diakses tgl 31 Desember 2009.

Taman Nasional Kutai. 2010. TN Kutai. Lisensi atribusi berbagi creative commons. http://wikipedia.org/wiki /Taman Nasional Kutai. Diakses tgl. 1 September 2010. 
Lampiran (Appendix) 1. Pola usahatani responden dari berbagai etnis di kawasan dan daerah penyangga $\mathrm{TN}$ Kutai (Farming pattern of respondents from different ethnic groups in TN Kutai and its buffer zone)

\begin{tabular}{|c|c|c|c|c|c|}
\hline \multirow{2}{*}{\multicolumn{2}{|c|}{ Parameter }} & \multicolumn{4}{|c|}{ Asal Etnis } \\
\hline & & Kutai & Dayak & Jawa & Bugis \\
\hline & $\begin{array}{l}\text { Jarak tempat tinggal } \\
\text { ke lahan garapan } \\
\text { (Distance from } \\
\text { settlement area to } \\
\text { cultivated land): } \\
\text { - Di dalam Desa (In } \\
\text { the village) } \\
\text { - Di TNK (In TNK) }\end{array}$ & $\begin{array}{l}1 \mathrm{~km} \\
15 \mathrm{~km}\end{array}$ & $\begin{array}{l}1 \mathrm{~km} \\
15 \mathrm{~km}\end{array}$ & $\begin{array}{c}0,5 \mathrm{~km} \\
1 \mathrm{~km}\end{array}$ & $\begin{array}{l}1 \mathrm{~km} \\
15 \mathrm{~km}\end{array}$ \\
\hline & $\begin{array}{l}\text { Jarak tempat tinggal } \\
\text { ke } \mathrm{S} \text {. Sangata } \\
\text { (Distance from } \\
\text { settlement to Sangata } \\
\text { river) }\end{array}$ & $0-200 \mathrm{~m}$ & $0-200 \mathrm{~m}$ & $100 \mathrm{~m}$ & $0-200 \mathrm{~m}$ \\
\hline & $\begin{array}{l}\text { Frekuensi interaksi } \\
\text { (Frequency of } \\
\text { interaction): } \\
\text { - Ke lahan garapan } \\
\text { di dalam desa (To } \\
\text { cultivated land } \\
\text { inside the village) }\end{array}$ & $\begin{array}{l}1 \mathrm{kali} / \mathrm{bulan} \text { atau } \\
\text { setiap hari saat } \\
\text { tanam (Once in a } \\
\text { month or everyday } \\
\text { during planting } \\
\text { period) }\end{array}$ & $\begin{array}{l}2 \text { kali/bulan atau } \\
\text { setiap hari saat } \\
\text { tanam (twice in a } \\
\text { month or everyday } \\
\text { during planting } \\
\text { period) }\end{array}$ & $\begin{array}{l}1 \mathrm{kali} / \mathrm{bulan} \text { atau } \\
\text { Setiap hari/saat } \\
\text { tanam (once in a } \\
\text { month or everyday } \\
\text { during planting } \\
\text { period) }\end{array}$ & - \\
\hline & - Ke TNK (toTNK) & $\begin{array}{l}2-5 \text { kali/bulan }(2-5 \\
\text { times } / \text { month })\end{array}$ & $\begin{array}{l}1 \mathrm{kali} / \mathrm{bulan} \text { (once } \\
\text { in a month) }\end{array}$ & $\begin{array}{l}5 \text { kali/bulan } \\
\text { setiap hari saat } \\
\text { musim tanam (five } \\
\text { times in a month } \\
\text { or everyday during } \\
\text { planting period) }\end{array}$ & $\begin{array}{l}2 \mathrm{kali} / \text { bulan ( } 2 \\
\text { times } / \text { month })\end{array}$ \\
\hline d. & $\begin{array}{l}\text { Tujuan berinteraksi } \\
\text { dengan TNK } \\
\text { (Purpose of } \\
\text { interaction with } \\
\text { TNK) }\end{array}$ & $\begin{array}{l}\text { Mendapatkan lahan } \\
\text { garapan untuk } \\
\text { budidaya kebun } \\
\text { pisang dan karet } \\
\text { (Obtaining land } \\
\text { for banana and } \\
\text { rubber tree } \\
\text { cultivation) }\end{array}$ & $\begin{array}{l}\text { Mendapatkan lahan } \\
\text { garapan untuk } \\
\text { budidaya tanaman } \\
\text { pangan semusim } \\
\text { dan karet } \\
\text { (obtaining land for } \\
\text { seasonal food crop } \\
\text { and rubber tree } \\
\text { cultivation) }\end{array}$ & $\begin{array}{l}\text { Mendapatkan } \\
\text { lahan untuk } \\
\text { budidaya tanaman } \\
\text { pangan semusim } \\
\text { (obtaining land } \\
\text { for annual food } \\
\text { crop cultivation) }\end{array}$ & $\begin{array}{l}\text { Mendapatkan } \\
\text { lahan garapan } \\
\text { untuk budidaya } \\
\text { tanaman pangan, } \\
\text { buah }^{2} \text { an dan } \\
\text { karet (obtaining } \\
\text { land food crop, } \\
\text { fruit trees and } \\
\text { rubber tree } \\
\text { cultivation) }\end{array}$ \\
\hline & $\begin{array}{l}\text { Teknik pembukaan } \\
\text { lahan yang diterap- } \\
\text { kan (Technique of } \\
\text { land preparation) }\end{array}$ & $\begin{array}{l}\text { Sistem tebang pilih } \\
\text { (Selected cutting } \\
\text { system) }\end{array}$ & $\begin{array}{l}\text { Sistem tebang habis } \\
\text { (clear cutting } \\
\text { system) }\end{array}$ & $\begin{array}{l}\text { Sistem tebang habis } \\
\text { (clear cutting } \\
\text { system) }\end{array}$ & $\begin{array}{l}\text { Sistim tebang } \\
\text { pilih (selected } \\
\text { cutting system) }\end{array}$ \\
\hline & $\begin{array}{l}\text { Pola tanam yang } \\
\text { diusahakan di lahan } \\
\text { garapan (Cropping } \\
\text { pattern applied on } \\
\text { cultivated land) }\end{array}$ & $\begin{array}{l}\text { - Tanaman } \\
\text { semusim (Annual } \\
\text { crops) } \\
\text { - Tanaman pisang } \\
\text { (Musa sp.) dan } \\
\text { karet (Hevea } \\
\text { brasiliensis } \\
\text { Muell. Arg) }\end{array}$ & $\begin{array}{l}\text { - Tanaman pangan } \\
\text { semusim } \\
\text { (seasonal food } \\
\text { crops) } \\
\text { - Padi (Oryza } \\
\text { sativa) dan Karet } \\
\text { (Hevea } \\
\text { brasiliensis } \\
\text { Muell. Arg) }\end{array}$ & $\begin{array}{l}\text { - Tanaman pangan } \\
\text { semusim (annual } \\
\text { food crops) }\end{array}$ & 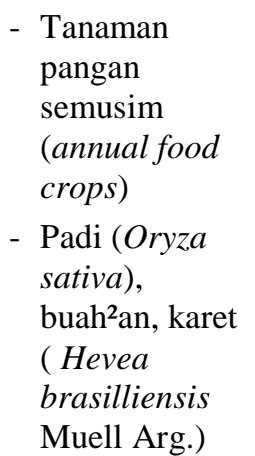 \\
\hline
\end{tabular}


Lampiran (Appendix) 1. Lanjutan (Continued)

\begin{tabular}{|c|c|c|c|c|c|}
\hline \multirow{2}{*}{\multicolumn{2}{|c|}{ Parameter }} & \multicolumn{4}{|c|}{ Asal Etnis } \\
\hline & & Kutai & Dayak & Jawa & Bugis \\
\hline $\mathrm{g}$ & $\begin{array}{l}\text { Penggunaan jenis } \\
\text { pohon (Use of trees): } \\
\text { - Untuk kayu } \\
\text { bangunan (For } \\
\text { housing } \\
\text { construction) }\end{array}$ & $\begin{array}{l}\text { - Ulin } \\
\text { (Eusideroxylon } \\
\text { zwageri Teijsm } \\
\text { \&Binn), meranti } \\
\text { (Shorea spp.), } \\
\text { kapur } \\
\text { (Dryobalanops } \\
\text { sp.), kayu laban } \\
\text { (Vitex pubescens } \\
\text { Vahl) }\end{array}$ & $\begin{array}{l}\text { - Ulin } \\
\text { (Eusideroxylon } \\
\text { swageri Teijsm } \\
\text { \&Binn.), meranti, } \\
\text { (Shorea } \text { spp.), } \\
\text { kapur } \\
\text { (Dryobalanops } \\
\text { sp.) }\end{array}$ & $\begin{array}{l}\text { - Kelapa (Cocos } \\
\text { nucifera Linn), } \\
\text { sengon } \\
\text { (Paraserianthes } \\
\text { falcataria Back), } \\
\text { kapok randu } \\
\text { (Ceiba petandra } \\
\text { (L.) Gaertn), } \\
\text { sawo (Achras } \\
\text { zapota), bambu } \\
\text { (Bambusa } \\
\text { vulgaris), pinus } \\
\text { (Pinus merkusii } \\
\text { Jungh.\&De } \\
\text { vriese) }\end{array}$ & $\begin{array}{l}\text { - Ulin } \\
\text { (Eusideroxylon } \\
\text { swageri Teijsm } \\
\text { \&Binn), } \\
\text { meranti } \\
\text { (Shorea spp.), } \\
\text { kapur } \\
\text { (Dryobalanops } \\
\text { spp.) }\end{array}$ \\
\hline & $\begin{array}{l}\text { - Untuk memasak } \\
\text { (For cooking) }\end{array}$ & $\begin{array}{l}\text { - Kayu laban (Vitez } \\
\text { pubescens Vahl.), } \\
\text { ulin } \\
\text { (Eusideroxylon } \\
\text { zwageri Teijsm } \\
\text { \&Binn.) }\end{array}$ & $\begin{array}{l}\text { - Kayu laban } \\
\text { (Vitez pubescens } \\
\text { Vahl.), ulin } \\
\text { (Eusideroxylon } \\
\text { zwageri Teijsm } \\
\text { \&Binn.) }\end{array}$ & $\begin{array}{l}\text { - Kayu laban } \\
\text { (Vitex pubescens } \\
\text { Vahl.), durian } \\
\text { (Durio zibethinus } \\
\text { Lamk), nangka } \\
\text { Artocarpus } \\
\text { heterophyllus } \\
\text { Lam.), cempedak } \\
\text { (Artocarpus } \\
\text { champedan) }\end{array}$ & $\begin{array}{l}\text { - Kayu laban } \\
\text { (Vitex } \\
\text { pubescens } \\
\text { Vahl.), ulin } \\
\text { (Eusideroxylon } \\
\text { swageri Teijsm } \\
\text { \&Binn.), kapur } \\
\text { (Dryobalanops } \\
\text { spp.), meranti } \\
\text { (Shorea } \text { spp.) }\end{array}$ \\
\hline & $\begin{array}{l}\text { - Untuk membuat } \\
\text { kapal (For ship } \\
\text { construction) }\end{array}$ & $\begin{array}{l}\text { - kapur } \\
\text { (Dryobalanops } \\
\text { sp.), meranti } \\
\text { (Shorea spp.) }\end{array}$ & $\begin{array}{l}\text { - kapur } \\
\text { (Dryobalanops } \\
\text { sp.), meranti } \\
\text { (Shorea } \text { spp.) }\end{array}$ & - & $\begin{array}{l}\text { - kapur } \\
\text { (Dryobalanops } \\
\text { sp.), meranti } \\
\text { (Shorea spp.) }\end{array}$ \\
\hline h. & $\begin{array}{l}\text { Pemanfaatan } \\
\text { tanaman obat (Use of } \\
\text { medicinal plants) }\end{array}$ & $\begin{array}{l}\text { Pasak bumi } \\
\text { (Eurycoma } \\
\text { longifolia) }\end{array}$ & $\begin{array}{l}\text { Pasak bumi } \\
\text { (Eurycoma } \\
\text { longifolia) }\end{array}$ & - & - \\
\hline i. & $\begin{array}{l}\text { Pemanfaatan jamur } \\
\text { (Use of mushroom) }\end{array}$ & $\begin{array}{l}\text { Jamur putih dan } \\
\text { jamur coklat (white } \\
\text { and brown } \\
\text { mushroom) }\end{array}$ & $\begin{array}{l}\text { Jamur putih dan } \\
\text { jamur coklat (white } \\
\text { and brown } \\
\text { mushroom) }\end{array}$ & - & - \\
\hline $\mathrm{j}$. & $\begin{array}{l}\text { Pemanfaatan satwa } \\
\text { untuk konsumsi dan } \\
\text { sesajen (Use of fauna } \\
\text { for consumption and } \\
\text { religious needs) }\end{array}$ & $\begin{array}{l}\text { Ikan (Nekton), } \\
\text { punai (Treron spp.), } \\
\text { payau (Rusa } \\
\text { unicolor) dan } \\
\text { pelanduk (Tragulus } \\
\text { napu) }\end{array}$ & $\begin{array}{l}\text { Babi (Sus } \\
\text { barbatus), ikan } \\
\text { (Nekton), punai } \\
\text { (Treron spp.), } \\
\text { pelanduk (Tragulus } \\
\text { napu) }\end{array}$ & Ikan (Nekton) & $\begin{array}{l}\text { Payau (Rusa } \\
\text { unicolor), } \\
\text { pelanduk } \\
\text { (Tragulus napu), } \\
\text { punai (Treron } \\
\text { spp.), ikan } \\
\text { (Nekton) }\end{array}$ \\
\hline $\mathrm{k}$. & $\begin{array}{l}\text { Jenis satwa yang } \\
\text { sering ditemukan } \\
\text { (Fauna species } \\
\text { frequently found) }\end{array}$ & $\begin{array}{l}\text { Orang utan (Pongo } \\
\text { pygmaeus), monyet } \\
\text { (Macaca } \\
\text { fascicularis), } \\
\text { bekantan (Nasalis } \\
\text { larvatus), payau } \\
\text { (Rusa unicolor), } \\
\text { pelanduk (Tragulus } \\
\text { napu), }\end{array}$ & $\begin{array}{l}\text { Orang utan (Pongo } \\
\text { pygmaeus), monyet } \\
\text { (Macaca } \\
\text { fascicularis), } \\
\text { bekantan (Nasalis } \\
\text { larvatus), payau } \\
\text { (Rusa unicolor), } \\
\text { pelanduk (Tragulus } \\
\text { napu), }\end{array}$ & $\begin{array}{l}\text { Orang utan (Pongo } \\
\text { pygmaeus), } \\
\text { monyet (Macaca } \\
\text { fascicularis), } \\
\text { biawak (Varanus } \\
\text { salvator), rusa } \\
\text { (Rusa timor), } \\
\text { pelanduk } \\
\text { (Tragulus napu), }\end{array}$ & $\begin{array}{l}\text { Orang utan } \\
\text { (Pongo } \\
\text { pygmaeus), } \\
\text { monyet (Macaca } \\
\text { fascicularis), } \\
\text { bekantan } \\
\text { (Nasalis } \\
\text { larvatus), }\end{array}$ \\
\hline
\end{tabular}


Lampiran (Appendix) 1. Lanjutan (Continued)

\begin{tabular}{llll}
\hline Parameter & \multicolumn{4}{c}{ Asal Etnis } \\
\cline { 2 - 4 } & \multicolumn{1}{c}{ Kutai } & \multicolumn{1}{c}{ Jawa } & \multicolumn{1}{c}{ Bugis } \\
\hline udang (Gammarus & udang (Gammarus & ular(Python & payau (Rusa \\
spp.), berbagai & spp.), berbagai & $\begin{array}{l}\text { raticulatus), buaya } \\
\text { (Crocodilus }\end{array}$ & unicolor), \\
jenis ikan & jenis ikan & parosus) dan & (Tragulus napu), \\
& & berbagai jenis & udang \\
& & burung (Aves) & (Gammarus \\
& & & spp.), berbagai \\
& & & jenis ikan \\
& & & (Nekton)
\end{tabular}

Sumber: Analisa Data Primer

Lampiran (Appendix) 2. Jenis ikan dari S. Sangata yang dikonsumsi dan diperjualbelikan (Fish species of Sangata River for consumption and sale)

\begin{tabular}{|c|c|c|}
\hline Nama Lokal (Local Name) & Nama Latin (ScientificName) & $\begin{array}{c}\text { Harga/kg (Pric } \\
\text { (Rp) }\end{array}$ \\
\hline Haruwan/Toman/Gabus & $\begin{array}{l}\text { Channa melasoma } \\
\text { Channa striata } \\
\text { Channa cyanospilos } \\
\text { Channa melanoptera } \\
\text { Channa pleurophithalmus } \\
\text { Channa marulioides }\end{array}$ & $35.000-40.000$ \\
\hline Sili & $\begin{array}{l}\text { Macrognathus aculatus } \\
\text { Macrognathus maculatus } \\
\text { Mastacembelus notophthalmus }\end{array}$ & 60.000 \\
\hline Sepat & $\begin{array}{l}\text { Trichogaster leerii } \\
\text { Trichogaster trichopteris } \\
\text { Trichogaster pectoralis } \\
\text { Trichopsis villata } \\
\text { Sphaerichthys selatanensis } \\
\text { Sphaerichthys vaillanti } \\
\text { Sphaerichthys osphromenoides } \\
\text { Sphaerichthys acrostoma }\end{array}$ & 10.000 \\
\hline Sidat & Anguilla marmorata & 25.000 \\
\hline Terumpah & $\begin{array}{l}\text { Cynoglossus puncticeps } \\
\text { Pseudothombus arsius }\end{array}$ & 15.000 \\
\hline Puyu & Anabas testudineus & 30.000 \\
\hline Batu & Helostoma temminchii & 15.000 \\
\hline Baung & $\begin{array}{l}\text { Mystus nemurus } \\
\text { Mystus gulio } \\
\text { Mystus nigriceps } \\
\text { Mystus micracanthus } \\
\text { Mystus bimaculatus }\end{array}$ & $35.000-40.000$ \\
\hline Patin & Pangasius nieuwenhuisii & $35.000-40.000$ \\
\hline Lele & Clarias leiacanthus & $20.000-25.000$ \\
\hline Keting & Arius spp. & $20.000-25.000$ \\
\hline Sembilang & Brachygobius aggregatus & $30.000-40.000$ \\
\hline Lumbat & $\begin{array}{l}\text { Ompok leiacanthus } \\
\text { Ompok euganeiatus }\end{array}$ & $20.000-30.000$ \\
\hline
\end{tabular}


Lampiran (Appendix) 2. Lanjutan (Continued)

\begin{tabular}{|c|c|c|}
\hline Nama Lokal (Local Name) & Nama Latin (ScientificName) & $\begin{array}{c}\text { Harga/kg (Price/kg) } \\
\text { (Rp) }\end{array}$ \\
\hline & $\begin{array}{l}\text { Ompok sabarus } \\
\text { Ompok hypophthalmus } \\
\text { Ompok bimaculatus } \\
\text { Kryptoptemus parvarialiss } \\
\text { Kryptoptemus palembangensis } \\
\text { Kryptoptemus schilbeides } \\
\text { Silurichthys hasseltii } \\
\text { Silurichthys phaiosoma }\end{array}$ & \\
\hline Julung-julung & $\begin{array}{l}\text { Hemirlamphodon phaisoma } \\
\text { Hemirlamphodon neglectus }\end{array}$ & $15.000-20.000$ \\
\hline Kerapu & Epinephelus spp. & $35.000-40.000$ \\
\hline Kakap & $\begin{array}{l}\text { Lutjanus fuscescens } \\
\text { Lutjanus maxweberi } \\
\text { Lutjanus johnii }\end{array}$ & $15.000-20.000,-$ \\
\hline Mujair & Oreochronius mossambicus & $10.000-15.000,-$ \\
\hline Belanak & Mugil cystachius & $30.000-40.000,-$ \\
\hline Ikan Mas & Cyprinus carpio & $34.000-40.000,-$ \\
\hline Seluang & $\begin{array}{l}\text { Punctius spp. } \\
\text { Rasbora spp. }\end{array}$ & $15.000-20.000,-$ \\
\hline Karper & $\begin{array}{l}\text { Osteochilus spp. } \\
\text { Oxygaster anomalura } \\
\text { Parachela hypophthalmus } \\
\text { Parachela oxygastroides }\end{array}$ & $10.000-15.000,-$ \\
\hline
\end{tabular}

Sumber: Analisis Data Primer 